\title{
Data report: preliminary assessment of Pleistocene sediment strength in the Ursa Basin (Gulf of Mexico continental slope) from triaxial and ring shear test data ${ }^{1}$
}

Sandra Meissl, ${ }^{2}$ Jonas Behrmann, ${ }^{2}$ and Jan H. Behrmann ${ }^{2}$

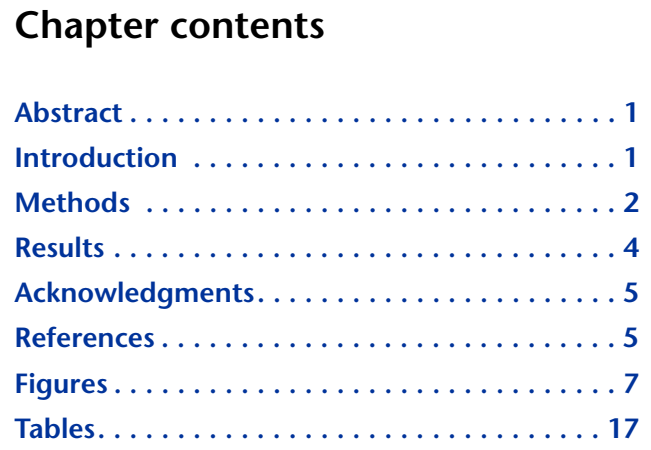

${ }^{1}$ Meissl, S., Behrmann, J., and Behrmann, J.H., 2010. Data report: preliminary assessment of Pleistocene sediment strength in the Ursa Basin (Gulf of Mexico continental slope) from triaxial and ring shear test data. In Flemings, P.B., Behrmann, J.H., John, C.M., and the Expedition 308 Scientists, Proc. IODP, 308: College Station, TX (Integrated Ocean Drilling Program Management International, Inc.). doi:10.2204/iodp.proc.308.211.2010 2IFM-GEOMAR, Wischhofstrasse 1-3, 24148 Kiel, Germany. Correspondence author: jbehrmann@ifm-geomar.de

\section{Abstract}

We report the preliminary results of a triaxial and ring shear study on clay-rich, fine-grained Pleistocene sediments cored in Ursa Basin, Gulf of Mexico continental slope. Specimens from Integrated Ocean Drilling Program (IODP) Expedition 308 Sites U1322 and U1324 document friction coefficients in the range of $0.13-0.31$, with internal angles of friction of $\sim 7.4^{\circ}-17.2^{\circ}$ in ring shear experiments. At intermediate (7.624 MPa) to high (15.237 MPa) overburden pressure, the majority of the samples tested show velocity weakening, whereas lower overburden pressures do not give a clear trend regarding velocity weakening or strengthening of the samples. In consolidated-undrained triaxial tests, peak shear stresses observed are between 27 and $140 \mathrm{kPa}$, with the strongest sample by far coming from a core catcher section. We suspect that this is an effect of fabric changes induced during hydraulic piston coring. One sample coming from the base of a mass transport deposit at Site U1322 is the weakest one tested. Young's moduli calculated range from 2 to $17.4 \mathrm{kPa}$. Stress paths indicate slight overconsolidation of the samples, which is in line with the information gained from preconsolidation stresses in other studies. Permeability determined from consolidation data is in the range of $10^{-16}$ to $10^{-17} \mathrm{~m}^{2}$, and hydraulic conductivity is around $10^{-9}$ to $10^{-10} \mathrm{~ms}^{-1}$. Grain density of the tested samples is around $2.7 \mathrm{~g} / \mathrm{cm}^{3}$, and water content ranges from $18.3 \%$ to $30.7 \%$.

\section{Introduction}

Integrated Ocean Drilling Program (IODP) Expedition 308 (see Behrmann et al., 2006) was dedicated to the study of overpressure generation and fluid flow focusing at the Gulf of Mexico continental margin. Of the two areas investigated by drilling, Ursa Basin (see, e.g., Winker and Booth, 2000; Winker and Shipp, 2002; or the "Expedition 308 summary" chapter for a detailed description of the geological setting) is the location where severe overpressure was identified (see the "Expedition 308 summary" chapter; Flemings et al., 2008) as a consequence of fine-grained muds being sedimented at very high rates, especially in the uppermost Pleistocene. In this setting, repeated slope failure occurred, with manifestations of mass transport deposits (MTDs) being most frequent where the measured overpressures are highest (see the "Expedition 308 summary" chapter; Sawyer et al., 2007; 
Flemings et al., 2008). This is clearly seen in Figure F1, which shows the combined lithologic, porosity, shear strength, and pore pressure logs for IODP Sites U1322 and U1324. The upslope site (U1324) shows lower overpressure and a smaller proportion of MTD in the section, which is in line with the predictions of the fluid focusing model for sedimentary prisms (e.g., Dugan and Flemings, 2000; Flemings et al., 2008).

When unconsolidated or poorly consolidated sedimentary rock masses are moved in the form of slumps, debris flows, or mud flows (e.g., Hein, 1985), there are variable degrees of clay realignment by remolding and shearing (e.g., Bohlke and Bennett, 1980). The clay fabric in particular seems to influence the geotechnical properties of the deposits (e.g., Bennett et al., 1981). It is thought that during mobilization the sediments become fluidized through temporary fabric collapse (in the case of sensitive clays) or by grains becoming buoyant during the ingress of externally derived fluids (e.g., Maltman and Bolton, 2003). Especially in the petrophysical core and log data from Site U1322 it is evident (Fig. F1) that porosity decrease and shear strength increase is not a simple function of depth but discontinuities are visible coincident with the boundaries separating units characterized by different modes of sediment transport (suspension and fallout versus MTD). Exceptionally low porosity observed near the bases of some of the MTDs speaks in favor of clay fabric collapse and concurrent fluidization as a consequence of the slumping process.

In order to learn more about the relationship of strength, fabric, and mineralogy of normally sedimented deposits and MTDs in the Ursa Basin, we have started to carry out a comprehensive investigation into the mechanical behavior, microfabrics, and textures of both types of sediment sampled at Sites U1322 and U1324. The results of the study will be published in full elsewhere after termination of the analytical work. To date, we have carried out a series of undrained triaxial shear tests on five whole-round core samples and ring shear tests on four samples. Here, we present these first results with some preliminary discussion. Ring shear testing (e.g., on remolded specimens) has the principal merit of being able to quantify the effect of mineral composition on the strength and frictional behavior of the material over a large range of confining pressures (e.g., Lupini et al., 1981). Also, velocity-dependence of shear strength can be investigated, giving answers to the question of whether the tested sediment reacts to accelerated shearing by weakening or strengthening. If velocity weakening is documented, then the material is thought to be especially prone to develop slumps and slides as result of a mechanical runaway situation. On the other hand, the principal reason to include triaxial testing in the program of strength investigation is that, in contrast to ring shear testing, triaxial testing is performed on undisturbed sediment material under undrained conditions. These conditions provide crucial information on the dependence of strength on fabrics and permit monitoring of excess pore water pressure changes during consolidation and shearing.

\section{Methods}

Triaxial tests were performed at University of Freiburg (Germany), using an ELE Digital Tritest 50 apparatus. The tests performed were consolidated and undrained (CU-test). In addition to sediment strength properties derived from the compression phase, permeability and hydraulic conductivity were determined on the basis of consolidation data. Setup and use of the apparatus are extensively documented in Roller et al. (2003) and Röser (2007). To date, a total of 13 tests (12 successful, 1 failed) were performed to approximately simulate in situ conditions in the overpressured Ursa Basin sediments, and results are shown below. Tests were carried out in constant strain rate mode to large $(\sim 20 \%)$ axial shortening in order to elucidate the postyield behavior. Material properties, like cohesion, coefficient of friction, and internal angles of friction, can be estimated from these tests. Consolidation of the samples after saturation was used to determine hydraulic conductivity and permeability in a routine akin to oedometer testing. A single triaxial test required $\sim 2$ weeks, including supplementary measurements, saturation, consolidation compression, and posttest data analysis. Two, or preferably three, tests were performed at confining pressures ranging from 0.5 to $1.8 \mathrm{MPa}$ on a whole-round sample at different confining pressures. This was achieved by dividing the whole round into two or three aliquots.

The maximum vertical load possible with the ELE Digital Tritest 50 apparatus is $7.5 \mathrm{kN}$ (Roller et al., 2003). The cylindrical specimens were cut from undisturbed whole-round core. Constrained by the size of the cell base, specimen diameter is $35 \mathrm{~mm}$ and specimen height chosen was $\sim 70-75 \mathrm{~mm}$ (DIN, 1990). Before installation on the cell base, the specimens were wrapped in filter paper, and porous disks were fitted to both ends of the specimen before being inserted into an impermeable rubber hose to avoid contact with the pressure cell fluid. The hose ensures that the specimen has no contact with the water filling the pressure cell. The cell base contains the influx to and drainage off of the cell and the 
specimen. Outlets and inlets are each equipped with sensors and connected through tubing with hydraulic pumps and/or with the volume change unit and pressure gauges.

Water content and grain density were measured prior to testing to correctly assess saturation pressures. Water content was measured following German Industry Standard DIN 18121 (DIN, 1998) by oven-drying $30-50 \mathrm{~g}$ of the sample material at $105^{\circ} \mathrm{C}$ for $12 \mathrm{~h}$. Oven temperature must not be higher in order to avoid the release of interlayer water in the clay minerals. Grain density was measured following German Industry Standard DIN 18124 (DIN, 1997).

A complete triaxial test comprises three phases: saturation, consolidation, and compression. Saturation of the sample with salt water is achieved by a stepwise increase of cell and pore pressure and is necessary to remove remaining air in the pore water and space (see Roller et al., 2003). Air in the pores corrupts the results of the compression test. To achieve saturation, the cell pressure and the pore pressure are increased simultaneously. We found that saturation of clayey to silty sediments required $\sim 3$ days. During the following $16-24 \mathrm{~h}$ of consolidation, isotopic equilibrium stress is achieved. During the compression stage, all valves from or to the triaxial cell base are closed to ensure an undrained test. Cell pressure is maintained by the water pumps while the specimen is brought to failure by a piston advancing at constant speed. Axial shortening rate was chosen to be $0.03 \mathrm{~mm} / \mathrm{min}$, which is sufficiently low to equilibrate to the confining pressure. Empirical tests (e.g., Röser, 2007) with similar materials have shown this to be the optimum shortening rate for undrained triaxial tests. Tests were terminated after $20 \%-28 \%$ of axial strain. During the test, the following parameters were measured in logarithmic time steps: axial displacement, cell pressure, pore pressure, backpressure (i.e., pore pressure in the sample during the consolidation and shearing stages), and axial force. From the data we calculated Young's modulus, cohesion, and angle of friction, using the routines outlined by Roller et al. (2003) or Röser (2007).

Permeability and hydraulic conductivity were determined by inserting consolidation data from triaxial testing into Darcy's law (see Röser, 2007, for details of the calculation procedure). During consolidation, an external pressure is imposed on the specimen, resulting in a pressure difference outside and inside the specimen. The resulting pore water flux out of the specimen through the porous discs at the specimen base and top was monitored by the volume change transducer. The resulting flux data enable the calculation of the total discharge. To define the hydraulic gradient, the length of the pressure drop was chosen to be half the length of the specimen, as the specimen was double drained.

Ring shear tests were performed at the RCOM Institute, University of Bremen (Germany), using a Bromhead RS ring shear apparatus (see Röser, 2007, for description of equipment and analytical procedures). For additional information on ring shear testing, the reader is referred to, for example, Bromhead (1979), Lupini et al. (1981), and Harris and Watson (1997). To simulate high-strain deformation during large movements on slump surfaces, water-saturated remolded sediments were sheared to high strains. It is the principal objective of the ring shear experiments to study the high-strain behavior. The use of remolded samples precludes the study of the effects of initial clay fabrics on strength. This, however, is taken to be of minor importance, as initial fabrics (e.g., degree of shape preferred orientation) in the clays studied is low in marine clays sedimented by suspension fallout from an oxic bottom water column (e.g., Kopf and Behrmann, 1997). Measurements were performed with axial loads ranging from 1 to $\sim 16 \mathrm{MPa}$ at four different rates of shear. A computer program stored all necessary data and directly computed the main shear parameters, such as shear stress, coefficient of friction, and internal angle of friction. Because of the very high clay content, the samples required very long consolidation periods, resulting in $\sim 10$ days duration for a single test. Four samples were measured until now, and the results are given below.

The experimental procedure is as follows. Annular remolded soil samples of $5 \mathrm{~mm}$ thickness and with inner and outer diameters of 20 and $50 \mathrm{~mm}$, respectively, are confined radially between concentric rings. The samples are compressed vertically between porous bronze loading plates by means of a lever loading system and kept under full seawater saturation during the whole test to ensure the appropriate hydration state for hydrous clay minerals in a marine environment (e.g., Kopf and Brown, 2003). One full test consisted of up to five incremental loading steps $(0.962,1.914,3.817,7.624$, and $15.237 \mathrm{MPa})$. Each step was preceded by at least $12 \mathrm{~h}$ of consolidation. This is necessary to eliminate effects on the shear strength of the tested material by incompressible pore water to be able to study the influence of mineralogy and granular structure on friction and strength. Following consolidation, shearing was performed at four different velocities: 0.005, 0.014, 0.18 , and $1.8 \mathrm{~mm} / \mathrm{min}$. Shearing is induced by torsion of the basal plate and the lower platen by a motor and gearbox. The settling of the upper plate during consolidation and shear was recorded by a displacement transducer on the top of the load 
hanger. Torque transmitted through the sample was recorded by a pair of matched load-recording proving rings bearing on a cross arm. The principal advantage of ring shear testing in comparison to direct shear testing (e.g., Berg, 1971) is the possibility to carry out isochoric simple shear to quasi-infinite strain. In nature, this is the case along the failure plane of a landslide or in a fault zone. Shearing at different shear velocities was used to determine the velocity dependence of friction, giving information about the weakening or strengthening capabilities of the tested material (e.g., Scholz, 1998).

\section{Results \\ Triaxial tests}

So far, four samples have been analyzed from Site U1324. Sedimentological description (see the "Site U1324" chapter) for the three samples of normally deposited material indicated slightly different settings: normally deposited hemipelagic sediments, levee turbidites, and distal turbidites. The samples were taken from depths between 154.4 and 406.7 meters below seafloor (mbsf). The results of the triaxial testing are given in Figures F2, F3, F4, and F5 and are tabulated in Table T1. Occasional initial offsets in the stress-strain diagrams (Figs. F3, F5) are attributed to sitting effects during the initial phase of compression. The offset of one of the stress paths from zero deviatoric stress in Figure F2 (experiment B at 1200 $\mathrm{kPa}$ cell pressure) is due to a minor axial load applied accidentally at the start of the experiment. Both types of deviations are minor, and we have chosen to display original experimental data and not to apply corrections here. Peak shear stress and Young's modulus were determined from the stress-strain data and changes in pore pressure during the course of the tests. Stress paths were recorded to build a base to derive friction coefficients, angles of friction, and cohesion. Supplementary measurements provided data on water content and grain density. All measured peak shear stresses are very small and lie between 45.3 and $140.7 \mathrm{kPa}$. The observed range of Young's modulus (from initial slope $\mathrm{M}_{0}$ in the stress-strain curve) is between $\sim 2$ and $6 \mathrm{kPa}$ in the samples, except for the sample from $153.4 \mathrm{mbsf}$, which has a distinctly higher Young's modulus (range: 13.6 to $17.4 \mathrm{kPa}$ ) and is by far the stiffest of all samples analyzed. As this is the only core catcher (CC denomination) sample that we have tested, we suspect that the high cohesion, peak shear strength, and derived Young's modulus have their origin in fabric changes that occurred at the bottom end of the core during the coring process when the hydraulic piston corer was advanced into the sediment. If this is so, then due care should be taken in the interpretation of geotechnical data from core catcher samples.

Permeability is in the range of $10^{-16}$ to $10^{-17} \mathrm{~m}^{2}$, and hydraulic conductivity determined during the consolidation stage is around $10^{-9}$ to $10^{-10} \mathrm{~ms}^{-1}$. Both types of values correspond well with determinations made by N.T.T. Binh et al. (unpubl. data) and Long et al. Where the data could be determined reliably, grain density of the tested samples is $\sim 2.7 \mathrm{~g} / \mathrm{cm}^{3}$, and water content ranges from $18.3 \%$ to $30.7 \%$. During testing, pore water pressure generally rose before reaching the yield point of the samples in all tests, within the first $5 \%-10 \%$ axial shortening. This probably relates to collapse of pore space when fractures or through-going shear zones are being formed in the samples. In the later part of the deformation history, pore pressure fell back to starting value or slightly below. When considering the stress-strain plots in detail, it is evident that all samples except for the hemipelagite from $153.4 \mathrm{mbsf}$ at Site U1324 do not weaken or strengthen during progressive deformation. The mentioned sample, however, shows cyclic changes in strength on the order of $\sim 5 \%-10 \%$.

One sample from the base of a major MTD at Site U1322 has been analyzed so far. Here, tests showed that the material is weaker than the normally sedimented material: peak deviatoric stress ranges from $\sim 27$ to $42 \mathrm{kPa}$, but Young's modulus is similar to the weak normally sedimented samples $(5.7-7.6 \mathrm{kPa})$. Figure $\mathbf{F} 6$ shows essential test data from this sample graphically, and the data are given in Table T1.

Stress paths from all five samples indicate that the material behaved in a somewhat overconsolidated fashion during the tests, but this effect is least notable in those samples that were consolidated and sheared at $\sim 1.7 \mathrm{MPa}$ confining pressure. This is an indication that the in situ effective stresses in the depth range investigated at Site U1324 may be close to this value. This interpretation is supported by the preconsolidation pressures of $\sim 1.5$ to $\sim 3 \mathrm{MPa}$ for the depth range between 300 and 500 mbsf, as determined for samples from Site U1324 by Long et al., and Dugan and Germaine. The almost exact similarity of the stress paths from two identical tests carried out on two aliquots of the whole-round sample from Core 308-U1324C-7H (Fig. F4) shows that tests are fully reproducible on similar materials.

Inferences that could be made about static coefficients of friction from stress path data in the consolidated-undrained tests are at a very preliminary stage, but inferences from Mohr envelopes would yield surprisingly high values ( 0.8 or more) for the normally sedimented samples at the range of mean effective stress considered (20-140 kPa). For the MTD sample, 
the friction coefficient estimate is definitely lower ( 0.44 at a mean effective stress range of $20-40 \mathrm{kPa}$ ). Inferred cohesion would be estimated in the range of $10-20 \mathrm{kPa}$, underlining the possible very weak nature of Ursa Basin sediments located at the base of MTDs.

\section{Ring shear tests}

Four samples, two each from Sites U1322 and U1324 have been analyzed so far, and the results are shown graphically in Figures F7, F8, F9, and F10 and are tabulated in Table T2. As experiments were under drained conditions, comparison with the results to those from the undrained triaxial tests is not straightforward, but some similarities are evident. Shear strength recorded at $\sim 1 \mathrm{MPa}$ normal stress (8 $\mathrm{kg}$ axial load) is very low at $100-300 \mathrm{kPa}$, rising more or less linearly to values between 3 and $4.5 \mathrm{MPa}$ at $\sim 16 \mathrm{MPa}$ normal stress (128 kg axial load).

Friction coefficients from all samples on the basis of these data are in the range of 0.13-0.31, with internal angles of friction of $\sim 7.4^{\circ}-17.2^{\circ}$. These are values not unusual for smectite-rich clays and muds, like those from the Ursa Basin. There is no obvious difference between the frictional behavior of the three samples from normally sedimented sections and the one from a MTD, except for the fact that the MTD material (sample from Core 308-U1322B-26H; see Fig. F9) is the weakest and shows the least sensitivity of frictional coefficients to changes in shearing rate and axial load. As samples subjected to ring shearing are remolded with no remaining primary microfabric, this is tentatively related to composition and/or the mode of clay flocculation and charging effects. Further investigations will show whether this is a phenomenon inherently related to mass transport deposits. More analyses of samples from both groups of sediments are needed, however, to further explore this question.

Regarding the sensitivity of strength with respect to changes in the velocity of shearing, some observations can be made in the uppermost diagrams of Figures F7, F8, F9, and F10. At high overburden pressure $(15.237 \mathrm{MPa})$, the reaction of the material to an increase in shearing velocity is generally strengthening in all samples, although in one case (Core 308U1322D-3H; Fig. F6) there is some weakening immediately after changing to a higher shearing rate. At intermediate overburden pressure $(7.624 \mathrm{MPa})$, the MTD sample (Core 308-U1322D-26H; Fig. F10) shows velocity softening when shearing is accelerated from 0.18 to $1.8 \mathrm{~mm} / \mathrm{min}$. Velocity softening is also observed in this sample at $3.817 \mathrm{MPa}$ overburden pressure. At intermediate overburden pressure, samples from Cores 308-U1322D-3H (Fig. F6) and
308-U1322B-4H (Fig. F8) show velocity softening, whereas the levee turbidite sample (Core 308U1324B-50H; Fig. F9) tends to harden over a wide range of overburden pressures when subjected to increases in shearing rate.

Overall, it can be shown (Fig. F1) that the peak shear strengths observed in the triaxial tests and cohesions computed from the ring shear test data (taking measured shear stress and friction coefficients at 0.962 and $1.914 \mathrm{MPa}$ into account) are mostly within the range of shear strengths determined shipboard during Expedition 308. Exceptions are the two samples from shallow depths at Site U1324 that show higher values in the experiments than in the shipboard data. At least for the sample tested triaxially, this is tentatively ascribed to the fact that a core catcher section was tested. We suspect that this could be an effect of fabric changes induced during the hydraulic piston coring.

\section{Acknowledgments}

We thank the participants and technical staff of Expedition 308 for their efforts and assistance in collecting samples for this study. Samples and data were provided by Integrated Ocean Drilling Program. We gratefully acknowledge the help of Geologisches Institut, Universität Freiburg (Germany), and RCOM, University of Bremen (Germany), for providing us with laboratory facilities to carry out the triaxial and ring shear experiments, respectively. This research was funded by Deutsche Forschungsgemeinschaft (DFG) with grant number Be1041/20-1 to Jan Behrmann.

\section{References}

Behrmann, J.H., Flemings, P.B., John, C.M., and the IODP Expedition 308 Scientists, 2006. Rapid sedimentation, overpressure, and focused fluid flow, Gulf of Mexico continental margin. Sci. Drill., 3:12-17. doi:10.2204/ iodp.sd.3.03.2006

Bennett, R.H., Bryant, W.R., and Keller, G.H., 1981. Clay fabric of selected submarine sediments: fundamental properties and models. J. Sediment. Res., 51(1):217-232. http://jsedres.sepmonline.org/cgi/reprint/51/1/217

Berg, J.S., 1971. Direct shear testing of marine sediment [M.S. thesis]. Naval Postgraduate Inst., Monterey, California.

Bohlke, B.M., and Bennett, R.H., 1980. Mississippi prodelta crusts: a clay fabric and geotechnical analysis. Mar. Geotechnol., 4(1):55-82. doi:10.1080/10641198009379813

Bromhead, E.N., 1979. A simple ring shear apparatus. Ground Eng., 12(5):40-44.

DIN, 1990. Soil, Testing Procedures and Testing Equipment: Determination of Shear Strength, Triaxial Test (German 
Standard DIN 18137-2): Berlin (Deutsches Institut für Normung).

DIN, 1997. Soil, Investigation and Testing: Determination of Density of Solid Particles-Capillary Pyknometer, Wide Mouth Pycnometer (German Standard 18124): Berlin (Deutsches Institut für Normung).

DIN, 1998. Soil, Investigation and Testing: Water ContentPart 1. Determination by Drying in Oven (German Standard DIN 18121-1): Berlin (Deutsches Institut für Normung).

Dugan, B., and Flemings, P.B., 2000. Overpressure and fluid flow in the New Jersey continental slope: implications for slope failure and cold seeps. Science, 289(5477):288-291. doi:10.1126/science.289.5477.288

Flemings, P.B., Long, H., Dugan, B., Germaine, J., John, C.M., Behrmann, J.H., Sawyer, D., and IODP Expedition 308 Scientists, 2008. Pore pressure penetrometers document high overpressure near the seafloor where multiple submarine landslides have occurred on the continental slope, offshore Louisiana, Gulf of Mexico. Earth Planet. Sci. Lett., 269(3-4):309-325. doi:10.1016/ j.epsl.2007.12.005

Harris, A.J., and Watson, P.D.J., 1997. Optimal procedure for the ring shear test. Ground Eng., 30(6):26-28.

Hein, F.J., 1985. Fine-grained slope and basin deposits, California continental borderland: facies, depositional mechanisms, and geotechnical properties. Mar. Geol., 67(3-4):237-262. doi:10.1016/0025-3227(85)90094-5

Kopf, A., and Behrmann, J.H., 1997. Fabric evolution and mechanisms of diagenesis in fine-grained sediments from the Kita-Yamato Trough, Japan Sea. J. Sediment. Res., 67(3):6590-600. http://jsedres.geoscienceworld.org/cgi/reprint/67/3/590

Kopf, A., and Brown, K.M., 2003. Friction experiments on saturated sediments and their implications for the stress state of the Nankai and Barbados subduction thrusts. Mar. Geol., 202(3-4):193-210. doi:10.1016/S00253227(03)00286-X

Lupini, J.F., Skinner, A.E., and Vaughan, P.R., 1981. The drained residual strength of cohesive soils. Geotechnique, 31:181-213.
Maltman, A.J., and Bolton, A., 2003. How sediments become mobilized. In van Rensbergen, P., Hillis, R.R., Maltman, A.J., and Morley, C.K. (Eds.), Subsurface Sediment Mobilization. Geol. Soc. Spec. Publ., 216(1):9-20. doi:10.1144/GSL.SP.2003.216.01.02

Röser, G., 2007. Petrography, physical properties, and geotechnical behavior of modern sediments, Southern Chile Trench [Ph.D. thesis]. Albert-Ludwigs-Universität Freiburg, Germany.

Roller, S., Pohl, C., and Behrmann, J.H., 2003. Data report: triaxial shear strength investigations of sediments and sedimentary rocks from the Japan Trench, ODP Leg 186. In Suyehiro, K., Sacks, I.S., Acton, G.D., and Oda, M. (Eds.), Proc. ODP, Sci. Results, 186: College Station, TX (Ocean Drilling Program), 1-19. doi:10.2973/ odp.proc.sr.186.115.2003

Sawyer, D.E., Flemings, P.B., Shipp, R.C., and Winker, C.D., 2007. Seismic geomorphology, lithology, and evolution of the late Pleistocene Mars-Ursa turbidite region, Mississippi Canyon area, northern Gulf of Mexico. AAPG Bull., 91(2):215-234. doi:10.1306/08290605190

Scholz, C.H., 1998. Earthquakes and friction laws. Nature (London, U. K.), 391(6662):37-42. doi:10.1038/34097

Winker, C.D., and Booth, J.R., 2000. Sedimentary dynamics of the salt-dominated continental slope, Gulf of Mexico: integration of observations from the seafloor, near-surface, and deep subsurface. Deep-Water Reservoirs of the World: Proc. GCSSEPM 20th Annu. Res. Conf., 10591086.

Winker, C.D., and Shipp, R.C., 2002. Sequence stratigraphic framework for prediction of shallow water flow in the greater Mars-Ursa area, Mississippi Canyon area, Gulf of Mexico continental slope [22nd Annual GCSSEPM Foundation Bob F. Perkins Research Conference, Houston, TX, 8-11 December, 2002]. (Abstract)

Initial receipt: 23 June 2008

Acceptance: 1 July 2010

Publication: 26 October 2010

MS 308-211 
Figure F1. Lithology, porosity, and peak shear strength measurements vs. depth for Sites U1322 and U1324 in the Ursa Basin (derived from shipboard data). Compaction-induced decrease of porosity and increase in shear strength with depth are clearly seen. Note high gradients near bases of some mass transport deposits. Blue bars $=$ cohesion estimated from strength and frictional behavior of ring shear tested samples, red bars $=$ ranges of peak shear strengths observed in triaxially tested material.

\section{Site U1324}

Site U1322

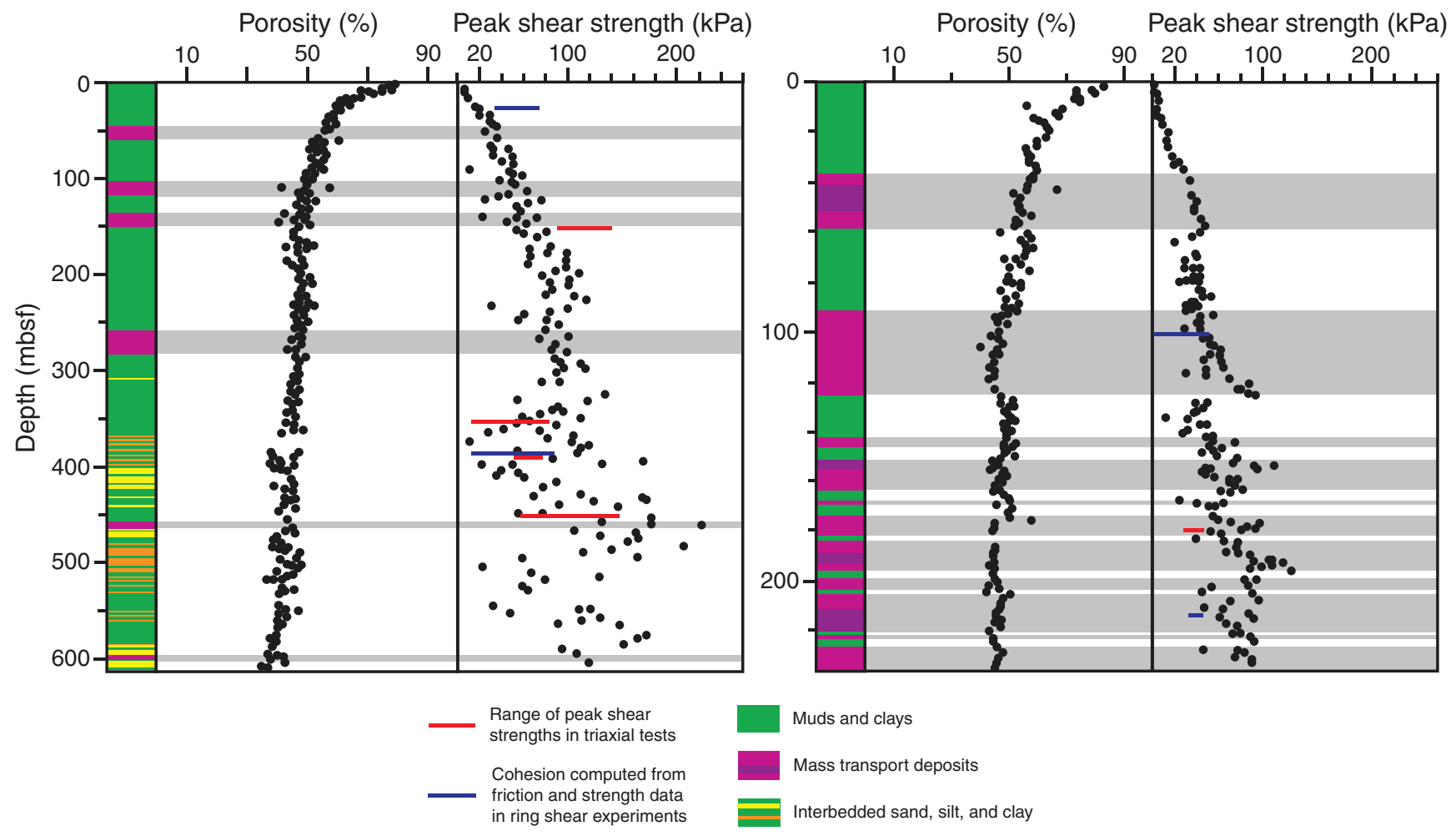


Figure F2. Triaxial test data of Sample 308-U1324B-17H-CC, a normally sedimented hemipelagite. A. Change in pore water pressure vs. axial strain. B. Deviatoric stress vs. axial strain. C. Effective stress path. $\mathrm{cp}=\mathrm{cell}$ pressure.

Triaxial test 308-U1324B-17H-CC
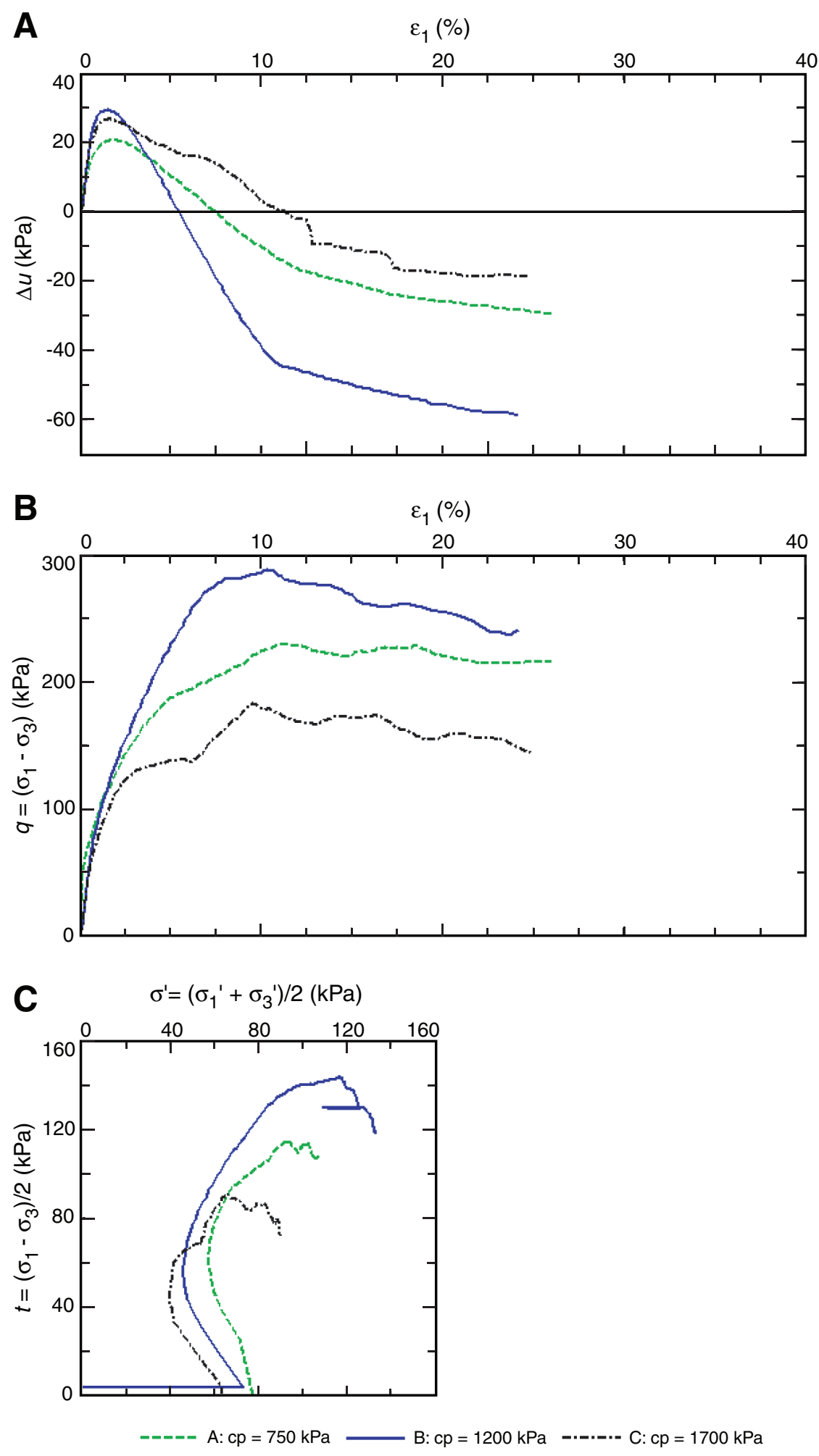
Figure F3. Triaxial test data of Sample 308-U1324B-44H-1, 100-120 cm, sedimentation by suspension fallout. A. Change in pore water pressure vs. axial strain. B. Deviatoric stress vs. axial strain. C. Effective stress path. cp = cell pressure.

Triaxial test 308-U1324B-44H
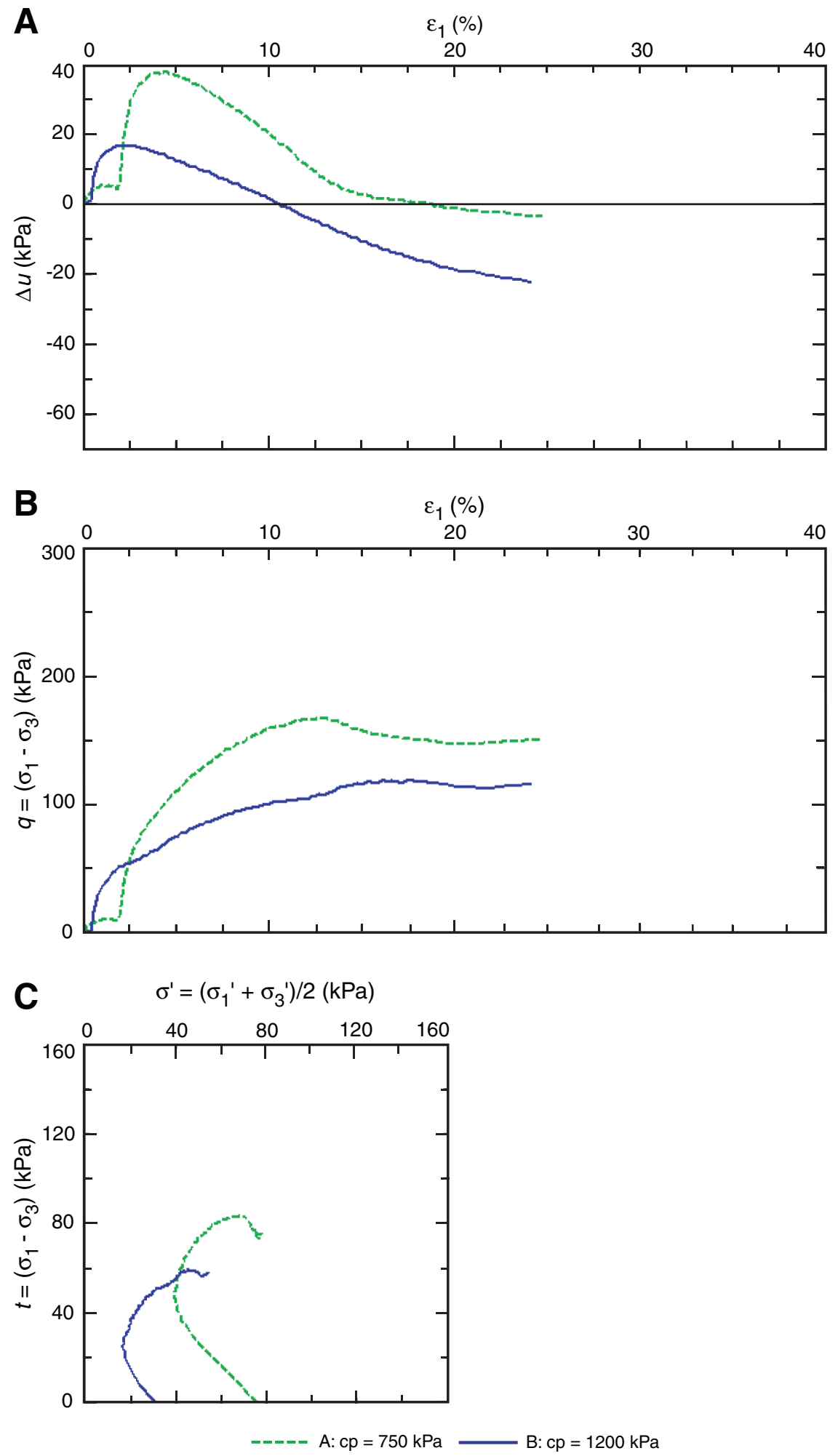
Figure F4. Triaxial test data of Sample 308-U1324B-50H-2, 110-130 cm, a levee turbidite. A. Change in pore water pressure vs. axial strain. B. Deviatoric stress vs. axial strain. C. Effective stress path. $\mathrm{cp}=$ cell pressure.

Triaxial test 308-U1324B-50H
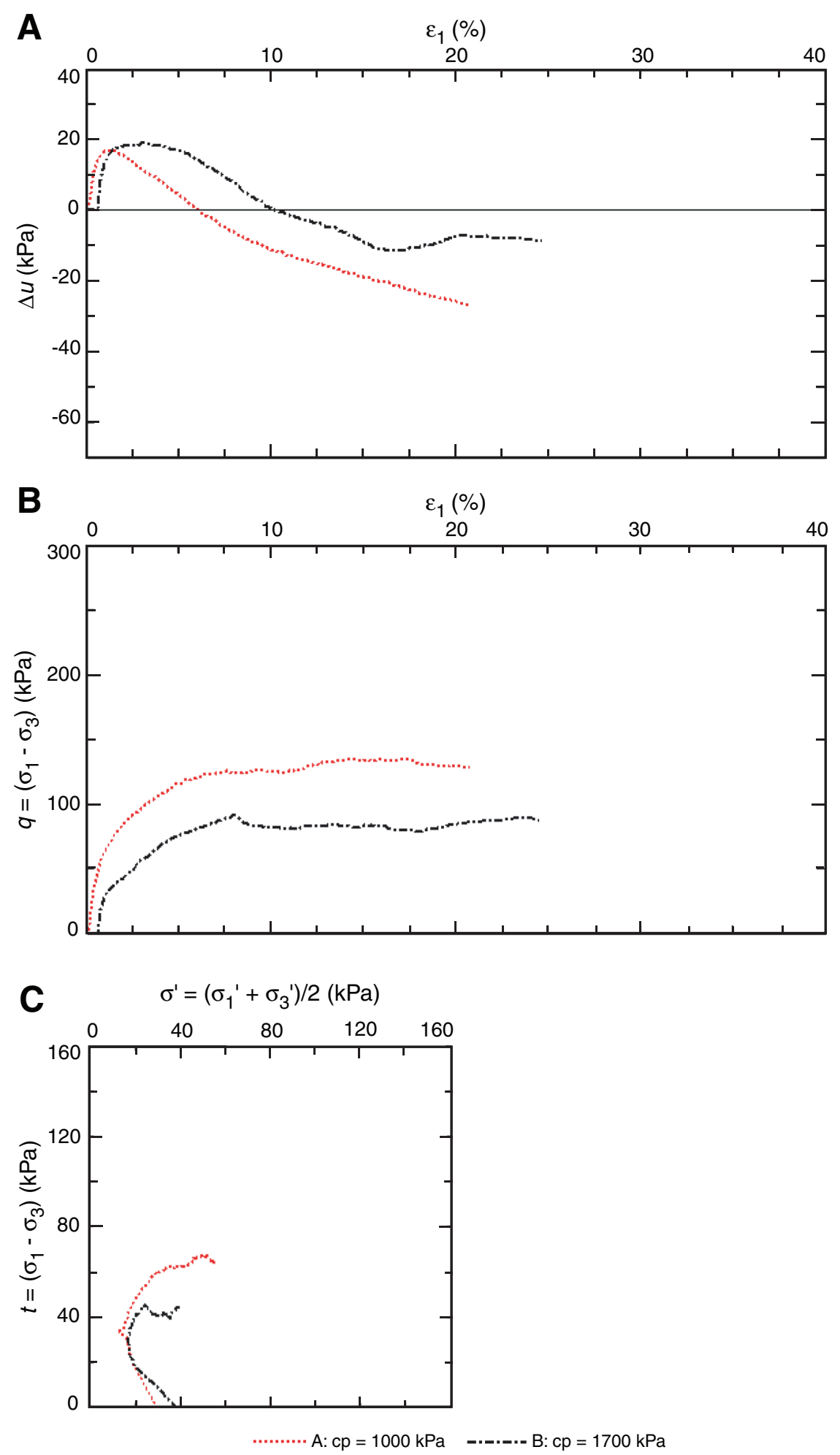
Figure F5. Triaxial test data of Core 308-U1324B-7H, a distal turbidite. A. Change in pore water pressure vs. axial strain. B. Deviatoric stress vs. axial strain. C. Effective stress path. $\mathrm{cp}=$ cell pressure.

Triaxial test 308-U1324C-7H-2
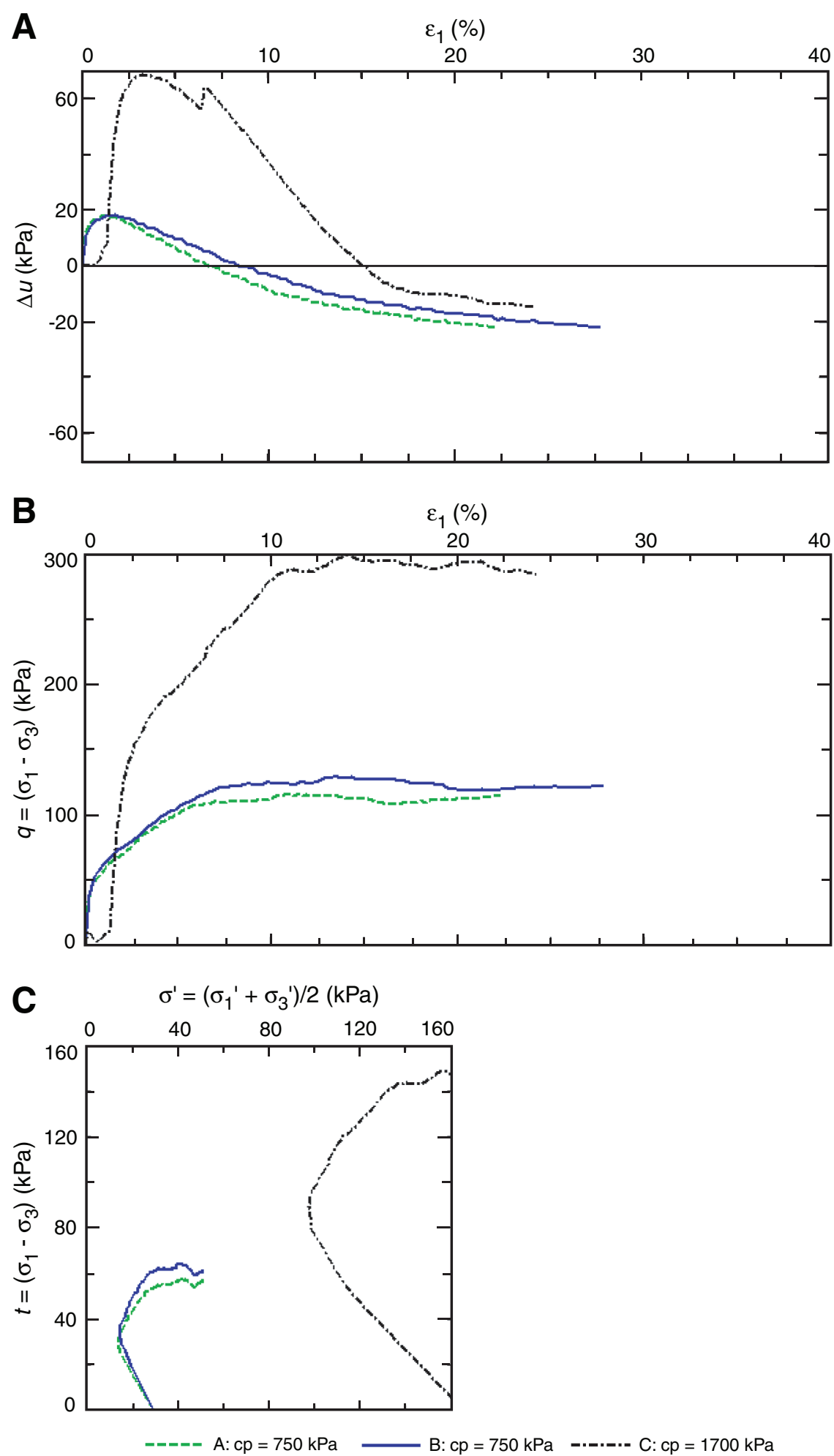
Figure F6. Triaxial test data of Core 308-U1322B-21H, located at the base of a mass transport deposit. A. Change in pore water pressure vs. axial strain. B. Deviatoric stress vs. axial strain. C. Effective stress path. $\mathrm{cp}=\mathrm{cell}$ pressure.

Triaxial test 308-U1322B-21H
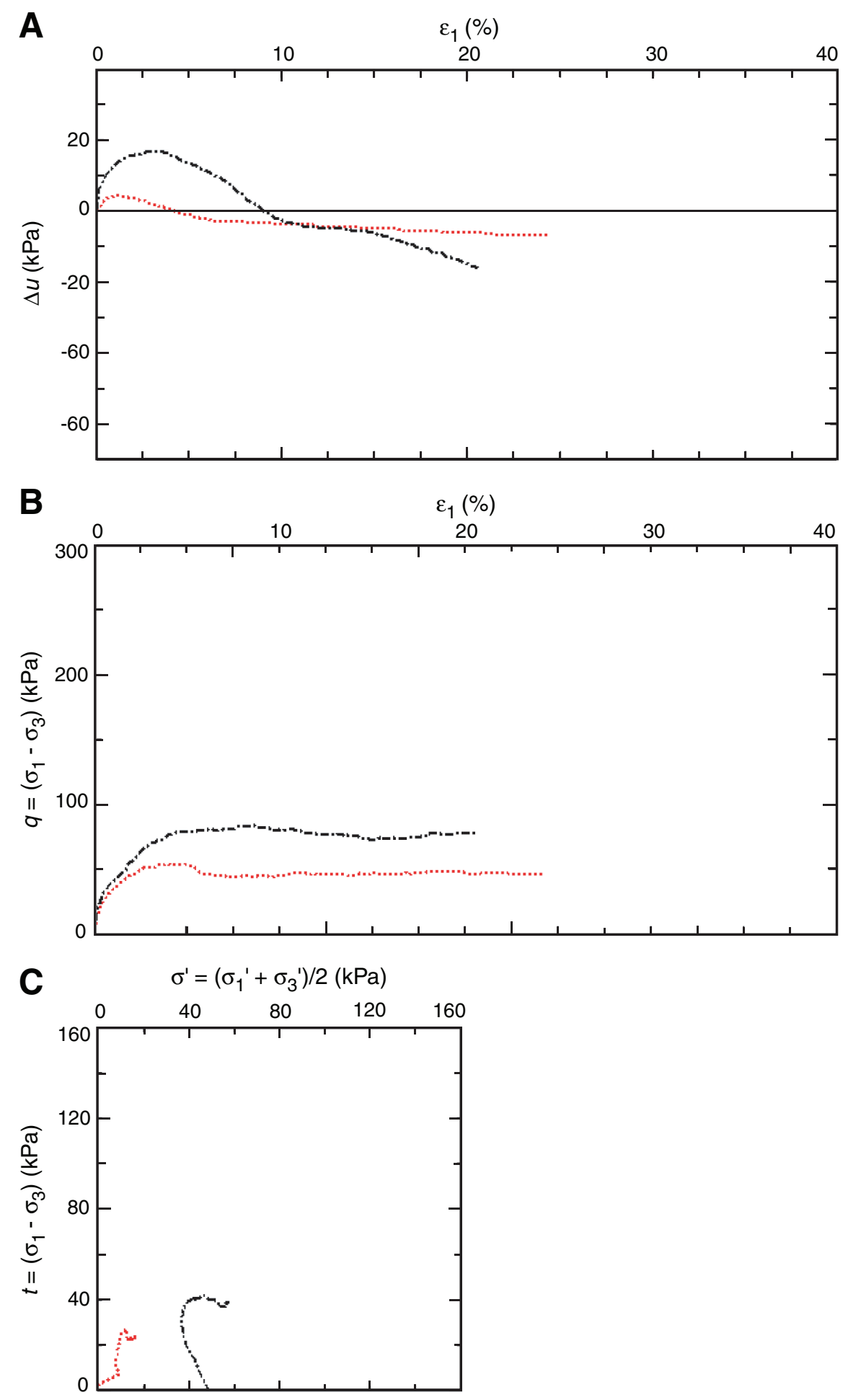

.......... A: $\mathrm{cp}=1000 \mathrm{kPa}$ 
Figure F7. Ring shear test data of Core 308-U1322B-26H, a mass transport deposit. A. Shear stress vs. displacement at different speeds. B. Shear stress vs. normal stress. C. Friction coefficient vs. normal stress.

Ring shear 308-U1322B-26H

A

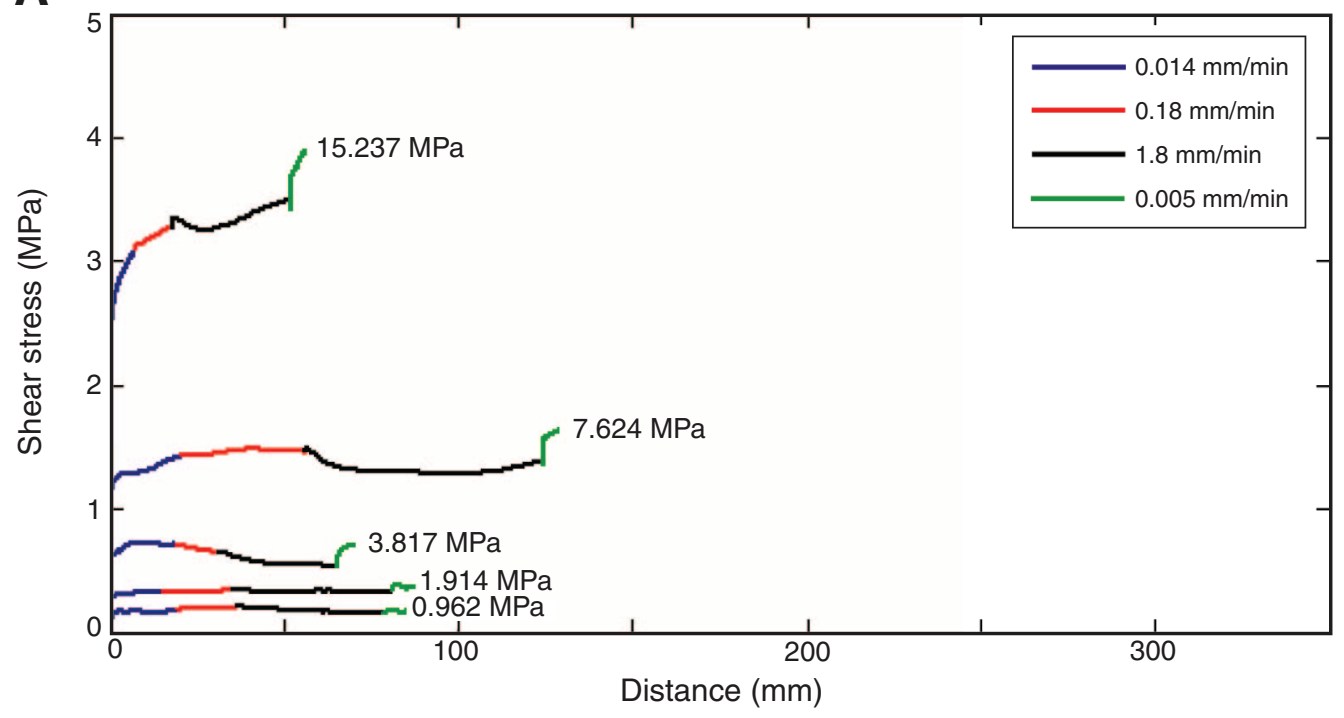

B

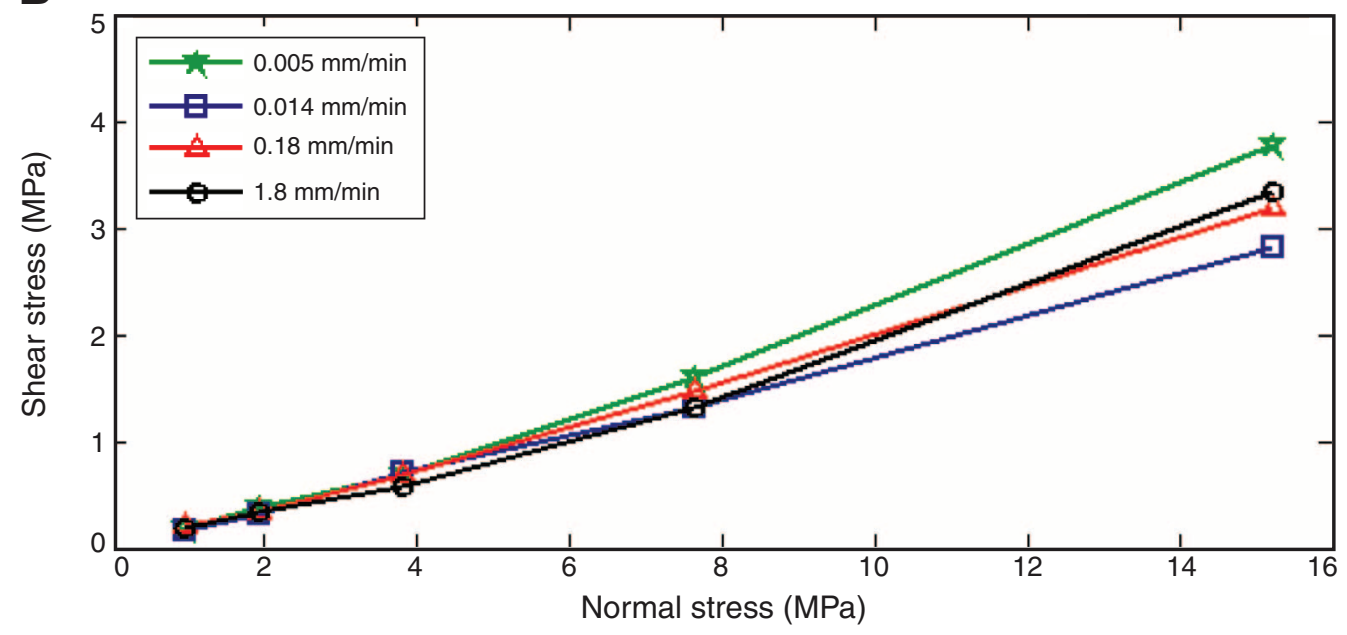

C

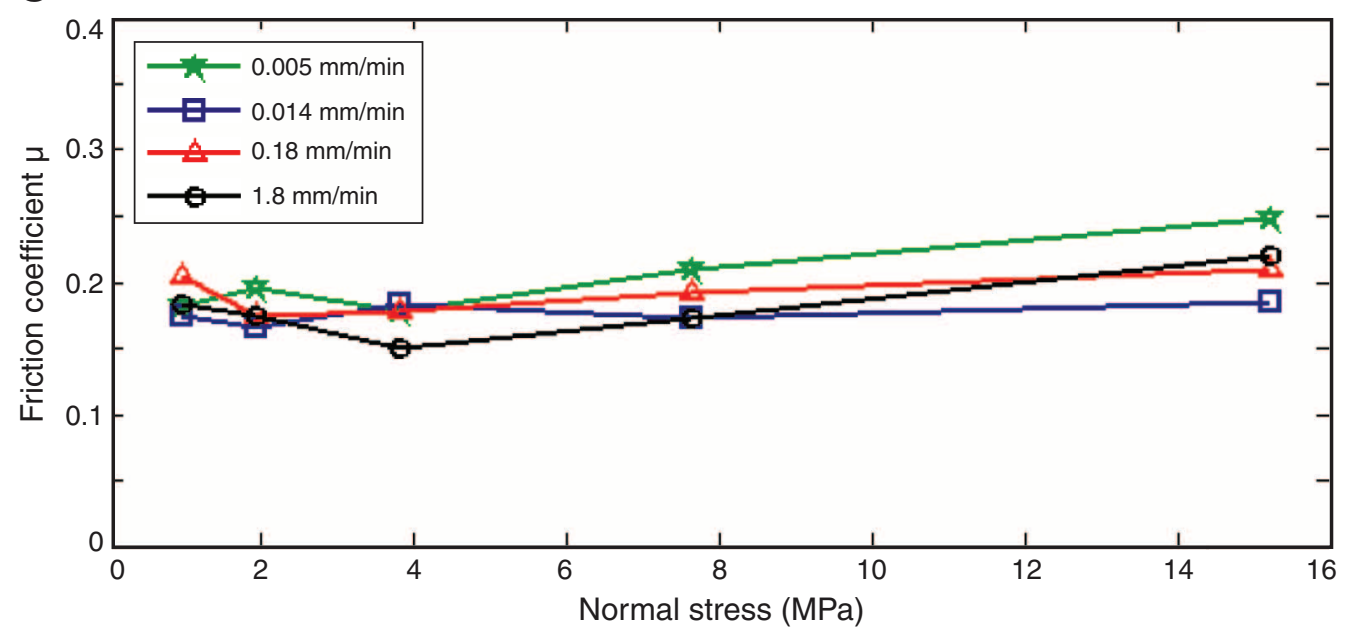


Figure F8. Ring shear test data of Core 308-U1322D-3H, a mass transport deposit. A. Shear stress vs. displacement at different speeds. B. Shear stress vs. normal stress. C. Friction coefficient vs. normal stress.

Ring shear 308-U1322D-3H
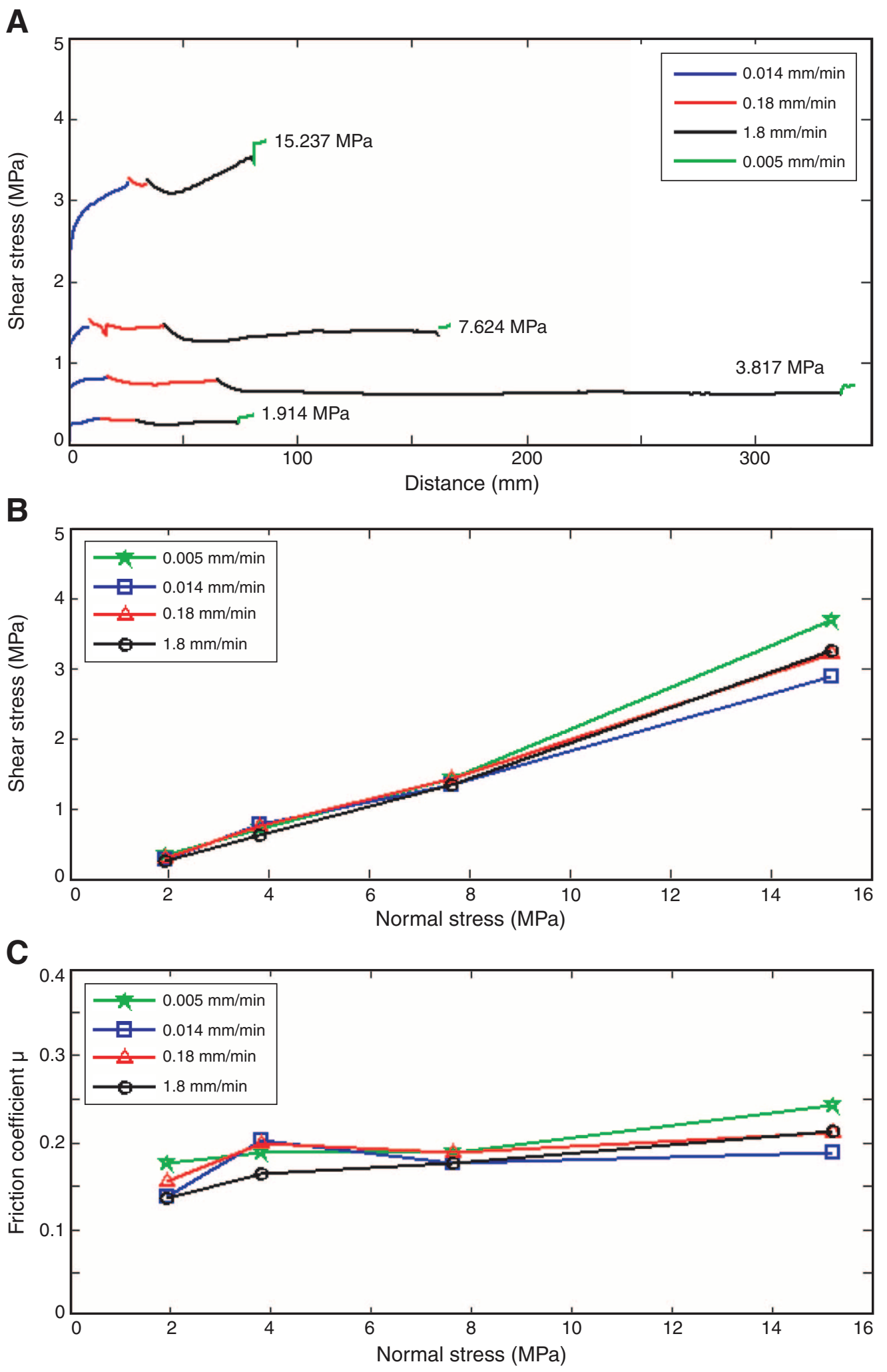
Figure F9. Ring shear test data of Core 308-U1324B-44H, a normally deposited sediment. A. Shear stress vs. displacement at different speeds. B. Shear stress vs. normal stress. C. Friction coefficient vs. normal stress.

Ring shear 308-U1324B-44H
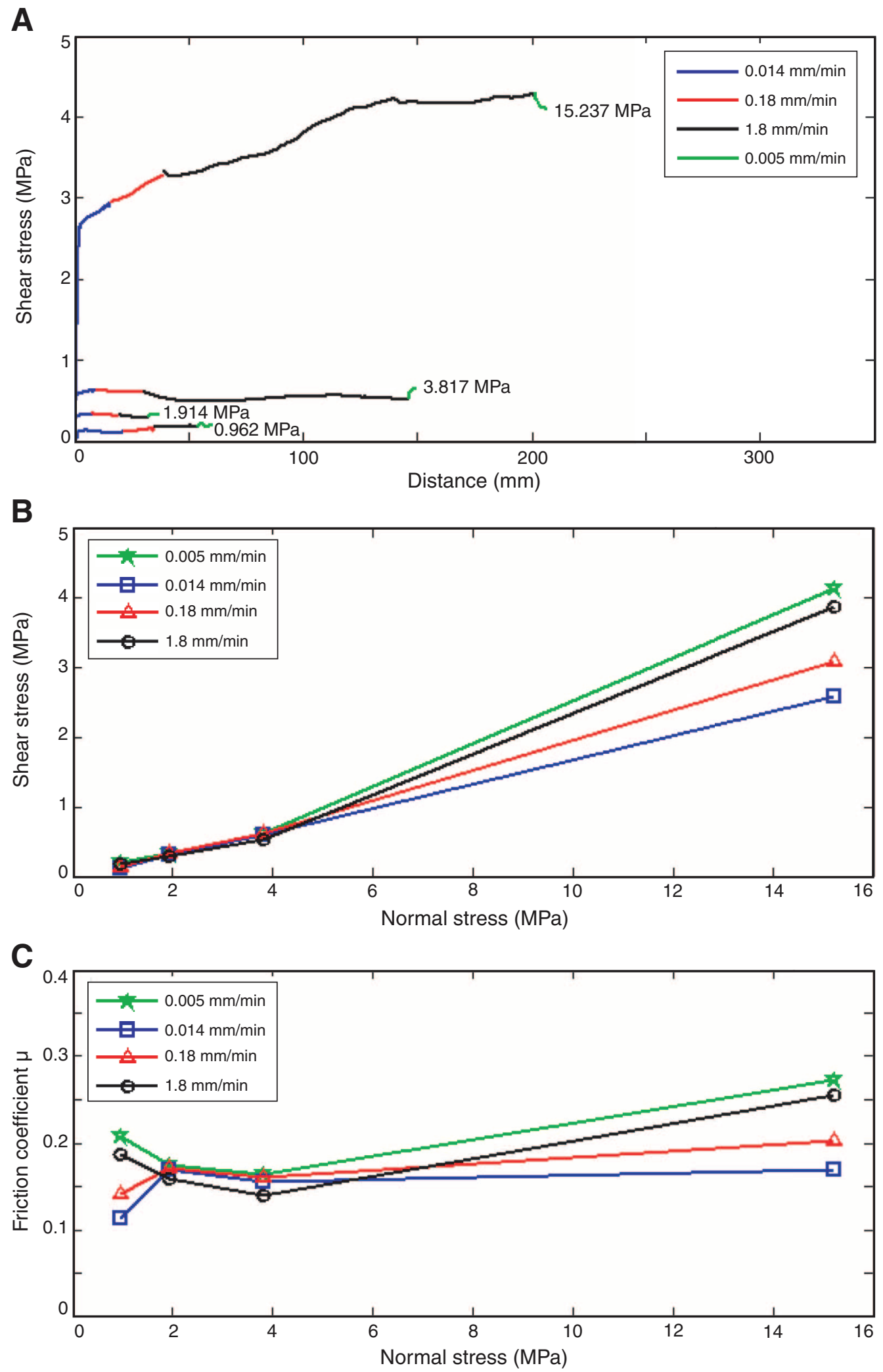
Figure F10. Ring shear test data of Core 308-U1324B-50H, a levee turbidite. A. Shear stress vs. displacement at different speeds. B. Shear stress vs. normal stress. C. Friction coefficient vs. normal stress.

Ring shear 308-U1324B-50H

A

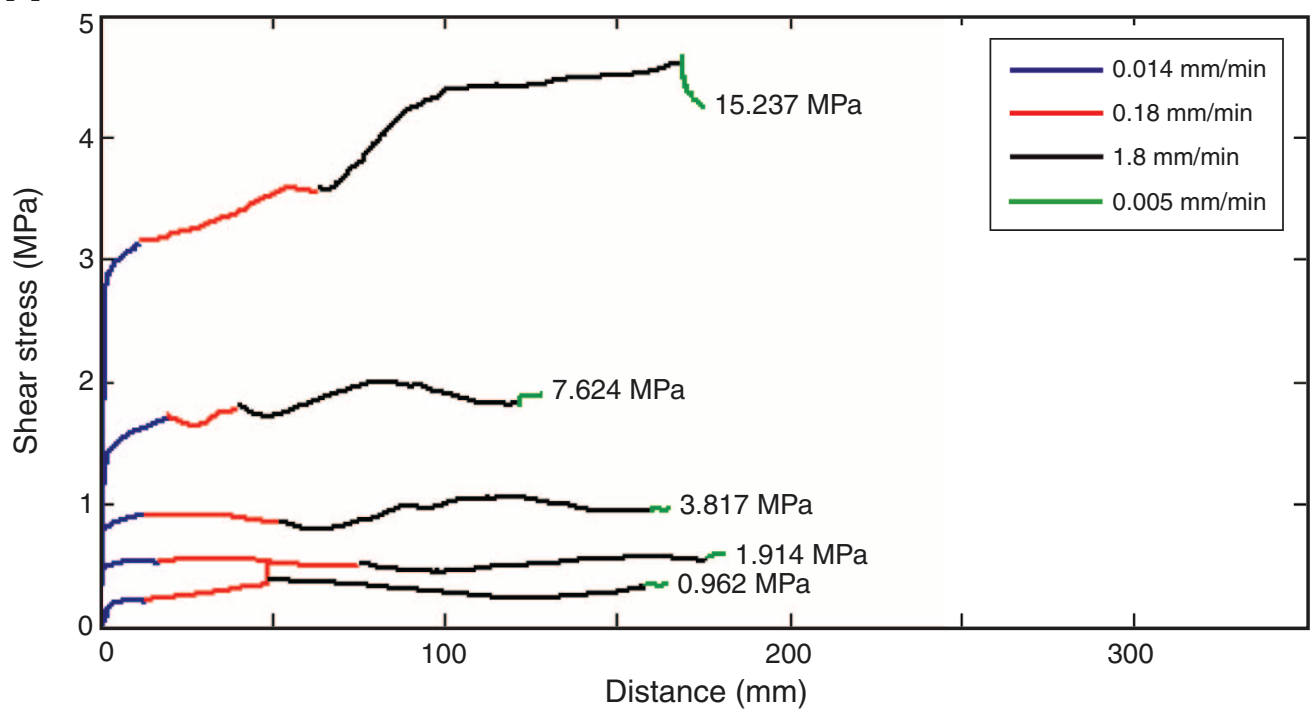

B

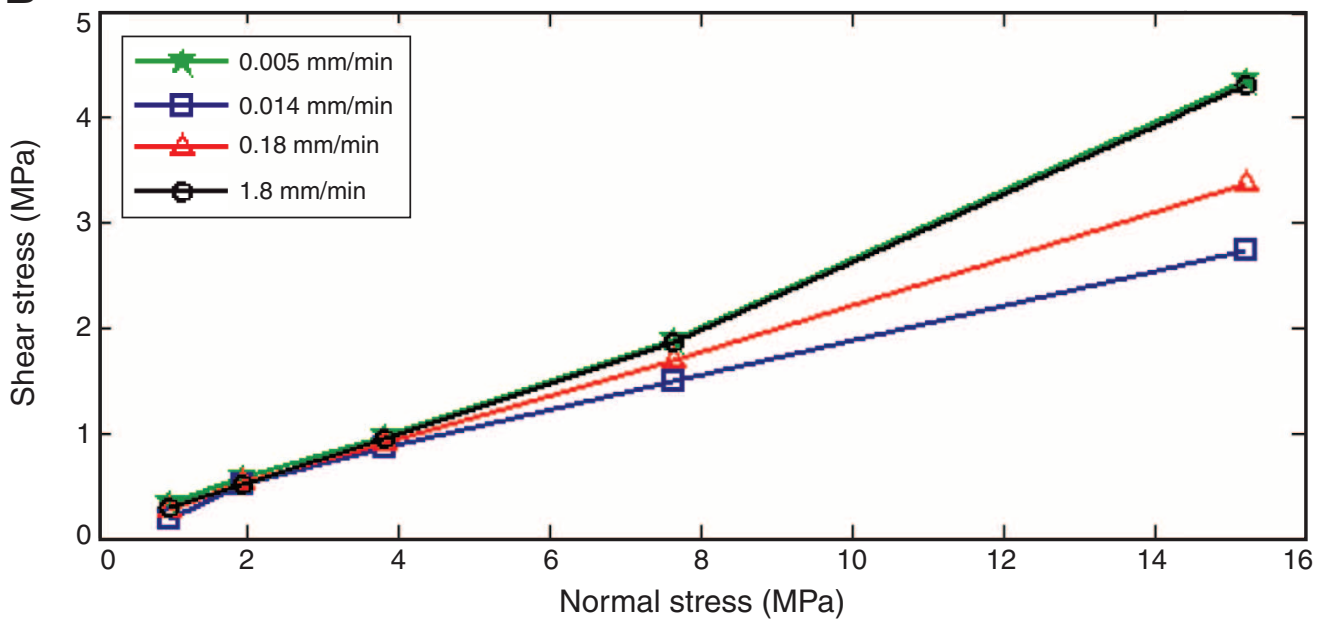

C

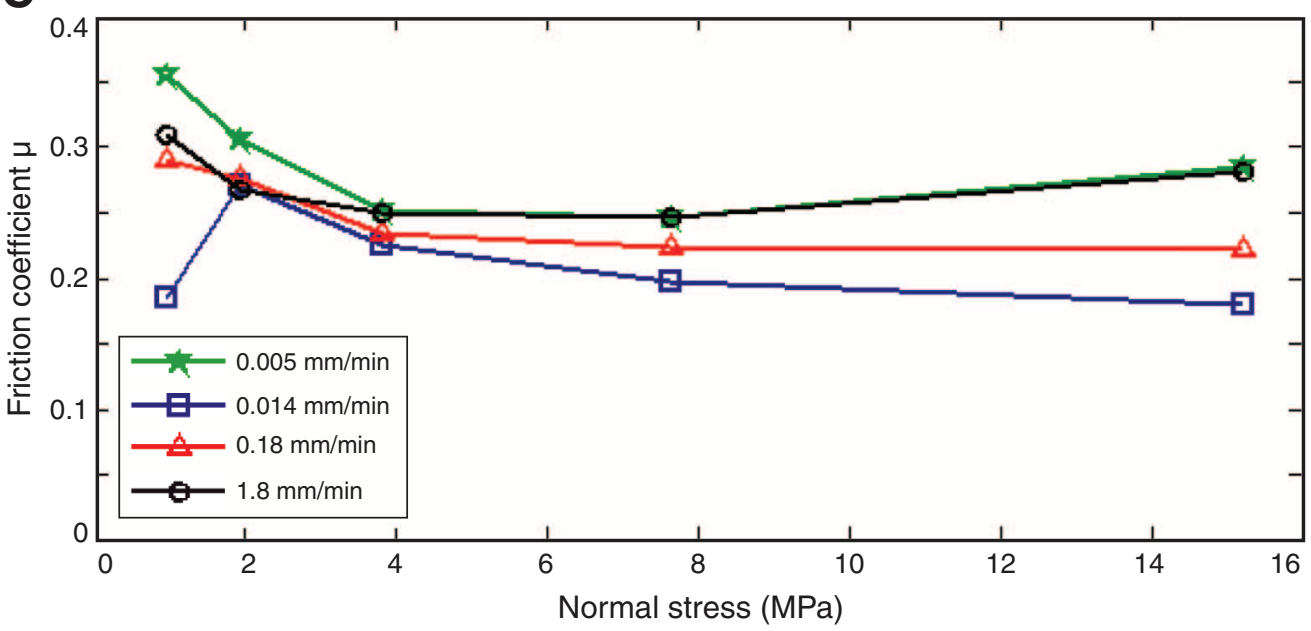


Table T1. Triaxial test data, Sites U1322 and U1324. (See table notes.)

\begin{tabular}{|c|c|c|c|c|c|c|c|c|c|c|c|}
\hline $\begin{array}{l}\text { Hole, core, section, } \\
\text { interval }(\mathrm{cm})\end{array}$ & $\begin{array}{l}\text { Depth } \\
\text { (mbsf) }\end{array}$ & Setting & $\begin{array}{l}\text { Saturation } \\
\text { pressure } \\
(\mathrm{kPa})\end{array}$ & $\begin{array}{l}\text { Consolidation } \\
\text { pressure } \\
(\mathrm{kPa})\end{array}$ & $\begin{array}{c}\text { Cell } \\
\text { pressure } \\
(\mathrm{kPa})\end{array}$ & $\begin{array}{l}\text { Maximum } \\
\text { shear stress } \\
\quad(\mathrm{kPa})\end{array}$ & $\begin{array}{l}\text { Young's } \\
\text { modulus } \\
(\mathrm{kPa})\end{array}$ & $\begin{array}{l}\text { Permeability } \\
\left(\mathrm{m}^{2}\right)\end{array}$ & $\begin{array}{l}\text { Hydraulic } \\
\text { conductivity } \\
(\mathrm{m} / \mathrm{s})\end{array}$ & $\begin{array}{l}\text { Water } \\
\text { content } \\
(\%)\end{array}$ & $\begin{array}{l}\text { Grain } \\
\text { density } \\
\left(\mathrm{g} / \mathrm{cm}^{3}\right)\end{array}$ \\
\hline \multicolumn{12}{|l|}{$308-$} \\
\hline U1324B-17H-CC & 153.36 & $\begin{array}{l}\text { Normally } \\
\text { sedimented }\end{array}$ & $\begin{array}{l}370.6 \\
734.9 \\
833.9\end{array}$ & $\begin{array}{r}668.1 \\
1423.5 \\
1606.5\end{array}$ & $\begin{array}{r}750 \\
1200 \\
1700\end{array}$ & $\begin{array}{l}115.71465 \\
140.729 \\
91.17590098\end{array}$ & $\begin{array}{l}13.61227 \\
15.13501 \\
17.40052\end{array}$ & $\begin{array}{l}2.46010 \mathrm{E}-17 \\
1.26257 \mathrm{E}-15 \\
1.47159 \mathrm{E}-16\end{array}$ & $\begin{array}{l}2.40820 \mathrm{E}-10 \\
1.23593 \mathrm{E}-08 \\
1.44055 \mathrm{E}-09\end{array}$ & 20.6652 & 2.5791 \\
\hline U1324B-44H-1, 100-120 & 353.7 & $\begin{array}{l}\text { Normally } \\
\text { sedimented }\end{array}$ & $\begin{array}{l}370 \\
596.7 \\
846.2\end{array}$ & $\begin{array}{c}700 \\
1159.6 \\
1687.9\end{array}$ & $\begin{array}{r}750 \\
1200 \\
1700\end{array}$ & $\begin{array}{c}83.37622 \\
59.12865 \\
6.088\end{array}$ & $\begin{array}{l}5.6499 \\
2.9541 \\
1.9699\end{array}$ & $\begin{array}{l}3.95703 \mathrm{E}-17 \\
1.31403 \mathrm{E}-16 \\
1.63191 \mathrm{E}-14\end{array}$ & $\begin{array}{r}-3.87356 \mathrm{E}-10 \\
1.28630 \mathrm{E}-09 \\
1.59748 \mathrm{E}-07\end{array}$ & 27.5655 & 2.7166 \\
\hline U1324B-50H-2, 110-130 & 390.5 & Levee turbidite & $\begin{array}{l}458.5 \\
846.2\end{array}$ & $\begin{array}{r}969.6 \\
1644.4\end{array}$ & $\begin{array}{l}1000 \\
1700\end{array}$ & $\begin{array}{l}67.25981 \\
45.37831\end{array}$ & $\begin{array}{l}5.848856647 \\
6.015\end{array}$ & $\begin{array}{r}2.5624 \mathrm{E}-16 \\
1.05190 \mathrm{E}-16\end{array}$ & $\begin{array}{l}2.50834 \mathrm{E}-09 \\
1.02970 \mathrm{E}-09\end{array}$ & 23.9 & 2.73 \\
\hline U1324C-7H-2, 15-40 & 406.65 & Distal turbidite & $\begin{array}{l}374 \\
374 \\
815.4\end{array}$ & $\begin{array}{r}720.6 \\
720.6 \\
1539.9\end{array}$ & $\begin{array}{r}750 \\
750 \\
1700\end{array}$ & $\begin{array}{c}57.74 \\
64.587 \\
149.179\end{array}$ & $\begin{array}{l}4.378300198 \\
3.751156543 \\
8.0631\end{array}$ & $\begin{array}{l}1.89251 \mathrm{E}-16 \\
1.74720 \mathrm{E}-16 \\
7.09299 \mathrm{E}-16\end{array}$ & $\begin{array}{l}1.85259 \mathrm{E}-09 \\
1.71034 \mathrm{E}-09 \\
5.78420 \mathrm{E}-09\end{array}$ & 18.33 & 2.708 \\
\hline U1322B-21H-2, 38-58 & 179.38 & Base of MTD & $\begin{array}{l}478.2 \\
789.7\end{array}$ & $\begin{array}{r}992.9 \\
1533.7\end{array}$ & $\begin{array}{l}1000 \\
1700\end{array}$ & $\begin{array}{l}26.936 \\
42.092\end{array}$ & $\begin{array}{l}5.700905028 \\
7.608794707\end{array}$ & $\begin{array}{l}4.00235 \mathrm{E}-16 \\
1.14712 \mathrm{E}-16\end{array}$ & $\begin{array}{l}3.91792 \mathrm{E}-09 \\
1.12292 \mathrm{E}-09\end{array}$ & 30.7514 & 2.6723 \\
\hline
\end{tabular}

Notes: Young's moduli from initial slope $\mathrm{M}_{0}$. Water content and grain density are given where these parameters could be reliably measured. MTD $=$ mass transport deposit. 


\begin{tabular}{|c|c|c|c|c|c|c|c|c|c|c|c|}
\hline $\begin{array}{l}\text { Hole, core, section, } \\
\text { interval }(\mathrm{cm})\end{array}$ & $\begin{array}{l}\text { Depth } \\
\text { (mbsf) }\end{array}$ & Setting & $\begin{array}{l}\text { Normal } \\
\text { stress } \\
\text { (MPa) }\end{array}$ & $\begin{array}{c}\text { Friction } \\
\text { coefficient } \mathrm{M} \text { at } \\
0.005 \mathrm{~mm} / \mathrm{min}\end{array}$ & $\begin{array}{c}\text { Internal angle } \\
\text { of friction at } \\
0.005 \mathrm{~mm} / \mathrm{min} \\
\left(^{\circ}\right)\end{array}$ & $\begin{array}{c}\text { Friction } \\
\text { coefficient } \mathrm{M} \text { at } \\
0.014 \mathrm{~mm} / \mathrm{min}\end{array}$ & $\begin{array}{c}\text { Internal angle } \\
\text { of friction at } \\
0.014 \mathrm{~mm} / \mathrm{min} \\
\left(^{\circ}\right)\end{array}$ & $\begin{array}{c}\text { Friction } \\
\text { coefficient } \mathrm{M} \text { at } \\
0.18 \mathrm{~mm} / \mathrm{min}\end{array}$ & $\begin{array}{c}\text { Internal angle } \\
\text { of friction at } \\
0.18 \mathrm{~mm} / \mathrm{min} \\
\left(^{\circ}\right)\end{array}$ & $\begin{array}{c}\text { Friction } \\
\text { coefficient } \mathrm{M} \text { at } \\
1.8 \mathrm{~mm} / \mathrm{min}\end{array}$ & $\begin{array}{c}\text { Internal angle } \\
\text { of friction at } \\
1.8 \mathrm{~mm} / \mathrm{min} \\
\left(^{\circ}\right)\end{array}$ \\
\hline \multirow{6}{*}{$\begin{array}{l}\text { 308- } \\
\text { U1322B-26H-3, 47-67 }\end{array}$} & & & & & & & & & & & \\
\hline & 213.9 & Mass transport & 0.962 & 0.182 & 10.332 & 0.174 & 9.871 & 0.205 & 11.585 & 0.184 & 10.426 \\
\hline & & deposit & 1.914 & 0.195 & 11.034 & 0.166 & 9.425 & 0.175 & 9.926 & 0.174 & 9.871 \\
\hline & & & 3.817 & 0.179 & 10.148 & 0.184 & 10.426 & 0.178 & 10.093 & 0.150 & 8.531 \\
\hline & & & 7.624 & 0.210 & 13.982 & 0.172 & 9.759 & 0.192 & 10.869 & 0.174 & 9.871 \\
\hline & & & 15.237 & 0.249 & 13.982 & 0.186 & 10.537 & 0.210 & 11.860 & 0.220 & 12.407 \\
\hline \multirow[t]{4}{*}{ U1322D-3H-3, 15-40 } & 103.0 & $\begin{array}{l}\text { Mass transport } \\
\text { deposit }\end{array}$ & $\begin{array}{l}0.962 \\
1.914\end{array}$ & 0.161 & 9.146 & $\begin{array}{l}0.161 \\
0.136\end{array}$ & $\begin{array}{l}9.146 \\
7.745\end{array}$ & 0.169 & 9.592 & 0.130 & 7.407 \\
\hline & & & 3.817 & 0.188 & 10.647 & 0.203 & 11.475 & 0.199 & 11.254 & 0.165 & 9.370 \\
\hline & & & 7.624 & 0.189 & 10.702 & 0.176 & 9.981 & 0.189 & 10.703 & 0.177 & 10.037 \\
\hline & & & 15.237 & 0.243 & 13.658 & 0.189 & 10.703 & 0.211 & 11.915 & 0.214 & 12.079 \\
\hline \multirow[t]{4}{*}{ U1324B-4H-1, 100-120 } & 24.0 & Normally & 0.962 & 0.117 & 6.673 & 0.116 & 6.617 & 0.142 & 8.082 & 0.208 & 11.745 \\
\hline & & sedimented & 1.914 & 0.174 & 9.871 & 0.169 & 9.592 & 0.172 & 9.759 & 0.158 & 8.979 \\
\hline & & & 3.817 & 0.163 & 9.258 & 0.155 & 8.817 & 0.161 & 9.146 & 0.139 & 7.913 \\
\hline & & & 15.237 & 0.272 & 15.216 & 0.169 & 9.592 & 0.203 & 11.475 & 0.255 & 14.306 \\
\hline \multirow[t]{5}{*}{ U1324B-50H-2, 110-130 } & 391.0 & Levee turbidite & 0.962 & 0.356 & 19.596 & 0.185 & 10.481 & 0.290 & 16.172 & 0.309 & 17.171 \\
\hline & & & 1.914 & 0.307 & 17.066 & 0.271 & 15.163 & 0.277 & 15.482 & 0.268 & 15.003 \\
\hline & & & 3.817 & 0.163 & 9.258 & 0.155 & 8.811 & 0.161 & 9.146 & 0.139 & 7.913 \\
\hline & & & 7.624 & 0.223 & 12.571 & 0.197 & 11.144 & 0.247 & 13.874 & 0.223 & 12.571 \\
\hline & & & 15.237 & 0.286 & 15.961 & 0.179 & 10.148 & 0.221 & 12.462 & 0.282 & 15.748 \\
\hline
\end{tabular}

